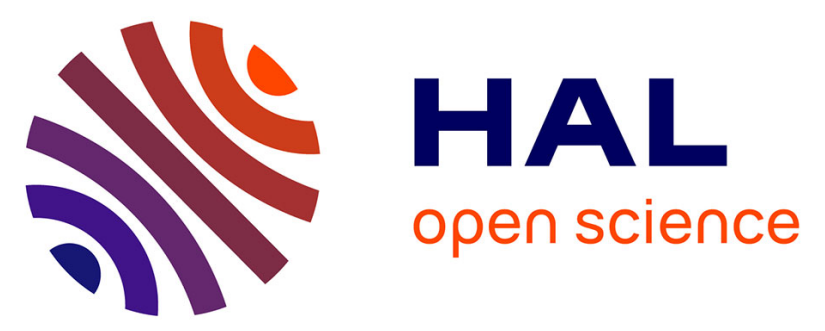

\title{
Essential oils composition of different Achillea santolina L. plant parts growing in Algeria
}

Tayeb Berramdane, Nadhir Gourine, Abdelghani Zitouni, Isabelle Bombarda, Mohamed Yousfi

\section{- To cite this version:}

Tayeb Berramdane, Nadhir Gourine, Abdelghani Zitouni, Isabelle Bombarda, Mohamed Yousfi. Essential oils composition of different Achillea santolina L. plant parts growing in Algeria. Oriental Pharmacy and Experimental Medicine, 2018, 18 (3), pp.265 - 269. 10.1007/s13596-018-0322-1 . hal01930273

\section{HAL Id: hal-01930273 \\ https://hal-amu.archives-ouvertes.fr/hal-01930273}

Submitted on 21 Nov 2018

HAL is a multi-disciplinary open access archive for the deposit and dissemination of scientific research documents, whether they are published or not. The documents may come from teaching and research institutions in France or abroad, or from public or private research centers.
L'archive ouverte pluridisciplinaire HAL, est destinée au dépôt et à la diffusion de documents scientifiques de niveau recherche, publiés ou non, émanant des établissements d'enseignement et de recherche français ou étrangers, des laboratoires publics ou privés.

\section{(c)(1)}

Distributed under a Creative Commons Attribution| 4.0 International License 


\title{
Essential oils composition of different Achillea santolina L. plant parts growing in Algeria
}

\author{
Tayeb Berramdane $^{1} \cdot$ Nadhir Gourine ${ }^{1}\left[\right.$ (D) Abdelghani Zitouni ${ }^{2} \cdot$ Isabelle Bombarda $^{3} \cdot$ Mohamed Yousfi $^{1}$
}

\begin{abstract}
The essential oils (EOs) of leaves, flowers and stems of Achillea santolina L. (Asteraceae) collected at complete flowering stage from Southwest of Algeria, were isolated by hydrodistillation and subsequently analyzed by means of GC and GC/MS. Quantitative and qualitative differences in chemical compositions between the studied parts of this plant were observed. The EOs were rich in oxygenated monoterpenes (65.91-79.94\%). The major constituents in the flowers, leaves and stems were: camphor $(68.12,65.17,55.72 \%), 1,8$-cineole $(8.22,4.77,0.7 \%)$ and $\alpha$-terpineol $(2.84,5.35,2.76 \%)$. The highest EO yields were obtained for the leaves and the flowers $(0.59$ and $0.49 \%$ "v/w", respectively), whereas, the stems were characterized by very weak yield value $(0.05 \%)$.
\end{abstract}

Keywords Achillea santolina L. · Essential oils $\cdot$ Leaves $\cdot$ Flowers $\cdot$ Stems $\cdot$ Camphor $\cdot$ Cineole

\section{Introduction}

The genus Achillea is one of the most important genres of the Asteraceae family and comprises 115 species, which are mainly distributed in Europe, Asia and North Africa (Bremer 1994). Achillea santolina is a small shrub grows in Algeria on arid environments and the edge of cultivated lands. There are about five species of Achillea which are widely distributed in Algeria; A. ligustica All., A. leptophylla M.B., A. odorata L., A. santolinö̈des Lag. and A. santolina L. (Quézel et al. 1962).

The aerial parts of different species of the genus Achillea are widely used in folk medicine due to various purposes and pharmacological properties in various biological activities, such as, anti-inflammatory (Benedek et al. 2007), antimicrobial (Sökmen et al. 2003; Ünlü et al. 2002), antispasmodic

Nadhir Gourine

n.gourine@lagh-univ.dz; gourine.nadir@gmail.com

$\triangle$ Mohamed Yousfi

yousfim8@gmail.com

1 Laboratoire des Sciences Fondamentales (LSF), Université Amar Télidji, Laghouat, BP. 37G, 03000 Laghouat, Algeria

2 ENS Kouba-Alger - École normale supérieure, Kouba, Algeria

3 CNRS, IRD, IMBE, Aix Marseille Univ., Univ. Avignon, Marseille, France
(Yaeesh et al. 2006), antiulcer (Abd-Alla et al. 2016), and antiradical activities (Ardestani and Yazdanparast 2007; Bali et al. 2015). Furthermore, this plant is also used as treatment for cancerous cells (Bali et al. 2015; Ghavami et al. 2010). More specifically for A. santolina, the dried aerial parts and flowers of this plant were used traditionally as antidiabetic and as anti-inflammatory. It was also used to relieve pain or dryness of the navel, stomach pain or gas and to relieve the symptoms of common cold (Al-Snafi 2013). Moreover, previous experimental investigations on A. santolina confirmed different biological and antioxidant activities of this plant (Al-Awwadi 2010, 2013; Al-Hindawi et al. 1989; Al-Snafi 2013; Ali and Abd El-Moaty 2017; Alkofahi et al. 1996; Ardestani and Yazdanparast 2006, 2007; El-Shazly et al. 2004; Khalil et al. 2009; Khoori et al. 1999; Nenaah 2014; Twaij et al. 1988; Zaringhalam et al. 2010). The volatile oil of A. santolina produced insecticidal and insect repellent activities on both domestic flies and honeybees (Mustafa and Al-Khazraji 2008).

To our best knowledge, A. santolina growing in Algeria did not exhibit any studies concerning the chemical composition of their essential oil on different plant parts. At the opposite side, and according to literature, there were only few reports (coming from different countries of origin) which investigated the chemical composition of the essential oil of the aerial parts (Bader et al. 2003; Berramdane et al. 2018; Mohamed and Abdelgaleil 2008; Nenaah 
2014; Rahimmalek et al. 2009) or their different parts (ElShazly et al. 2004; Motavalizadehkakhky et al. 2013a, b). The aim of this study was to investigate difference in amount and chemical composition of flowers, leaves and steams volatile oils from $A$. santolina.

\section{Materials and methods}

\section{Plant collection}

The aerial parts of A. santolina L. (at their full flowering phenological stage) were collected at the end of May 2014 from an area of the high plateaus which belongs to the region of Tousmouline at the wilaya of El-Bayadh. More specifically, the geographical coordinates of the exact location of this region of collection are $33^{\circ} 38^{\prime} 12^{\prime \prime} \mathrm{N}$ and $0^{\circ} 18^{\prime} 51^{\prime \prime} \mathrm{E}$, and its altitudes is $1191 \mathrm{~m}$. The plant was identified by Dr. Seridi abdel-kadir from department of Agronomy, University of Laghouat. Voucher specimens have been deposited in the herbarium of the National Agronomic Institute of Algiers (N.A.I.), Algeria (Herbarium No. P: 11).

\section{Essential oil extraction}

The plant material samples were dried in a shade at ambient temperature; subsequently, they were carefully milled; after that they were hydrodistilled for $3 \mathrm{~h}$ using a Clevenger type apparatus. The essential oil samples were recovered from the distillate with diethyl-ether solvent and then dried overnight using anhydrous sodium sulfate $\mathrm{Na}_{2} \mathrm{SO}_{4}$. After filtration the extract solutions, they were reduced at room temperature under light vacuum pressure using rotary evaporator (Rotavap). Finally, the obtained EO samples were stored at $\left(+4{ }^{\circ} \mathrm{C}\right)$ until analysis.

\section{Essential oil analysis}

Analysis was carried out by gas chromatography (GC) using two columns and by gas chromatography-mass spectroscopy (GC/MS).

\section{Gas chromatography (GC)}

For the first column (ploar), a CP-Varian 3800 gas chromatograph was used with a flame ionization detector (FID), and a UB-Wax fused silica capillary column $(60 \mathrm{~m} \times 0.32 \mathrm{~mm}$, $0.25 \mu \mathrm{m}$ film thickness). Oven temperature was programmed from 50 to $250{ }^{\circ} \mathrm{C}$ at a rate of $3{ }^{\circ} \mathrm{C} \cdot \mathrm{min}^{-1}$ and held at $250{ }^{\circ} \mathrm{C}$ for $10 \mathrm{~min}$. Injector and detector temperatures were set at 250 and $260{ }^{\circ} \mathrm{C}$, respectively. Helium was the carrier gas at a flow rate of $1 \mathrm{~mL} / \mathrm{min}$. Splitting ratio 1:50.
For the second column (aploar), analytical GC was carried out in a Hewlett-Packard 6890 (Agilent Technologies, Palo Alto, CA, USA) gas chromatograph with a HP GC ChemStation Rev. A.05.04 data handling system, equipped with a single injector and flame ionization detection (FID) system. A graphpak divider (Agilent Technologies, part no. 5021-7148) was used for sampling to fused silica capillary column HP-5 (polydimethylsiloxane $30 \mathrm{~m} \times 0.20 \mathrm{~mm}$ i.d., film thickness $0.20 \mu \mathrm{m})$. Oven temperature program: $70-220^{\circ} \mathrm{C}\left(3{ }^{\circ} \mathrm{C} \cdot \mathrm{min}^{-1}\right), 220^{\circ} \mathrm{C}(15 \mathrm{~min})$; injector temperature: $250{ }^{\circ} \mathrm{C}$; carrier gas: helium, adjusted to a linear velocity of $30 \mathrm{~cm} \mathrm{~s}^{-1}$; splitting ratio 1:40; detectors temperature: $250{ }^{\circ} \mathrm{C}$.

\section{Gas chromatography-mass spectroscopy (GC/MS)}

GC-MS was carried out in a Hewlett-Packard 6890 gas chromatograph fitted with a HP-1 fused silica column (polydimethylsiloxane $30 \mathrm{~m} \times 0.25 \mathrm{~mm}$ i.d., film thickness $0.25 \mu \mathrm{m}$ ), interfaced with an Hewlett-Packard mass selective detector 5973 (Agilent Technologies) operated by HP Enhanced ChemStation software, version A.03.00. GC parameters as described above; interface temperature: $250{ }^{\circ} \mathrm{C}$; MS source temperature: $230{ }^{\circ} \mathrm{C}$; MS quadrupole temperature: $150{ }^{\circ} \mathrm{C}$; ionization energy: $70 \mathrm{eV}$; ionization current: $60 \mu \mathrm{A}$; scan range: $35-350$ units; scans $\mathrm{s}^{-1}$ : 4.51 .

Components of each EO sample were identified by their linear retention indices on both UB-Wax and SPB-1 columns. Linear retention indices were calculated relative to linear homologous series of $n$-alkanes $\mathrm{C}_{8}-\mathrm{C}_{24}$. The identifications of the components were based on the comparison of their mass spectra with those of Wiley and NIST (National Institute of Standards and Technology) libraries, as well as by comparison of their retention indices with those of the values of a homemade database.

\section{Results and discussion}

The essential oils obtained by hydrodistillation from the flowers, the leaves and the stems of A. santolina presented strong characteristic odors and yellow colors. The EO yields were varying from moderate to weak values. The maximum yield was recorded for the leaves part with a value of $0.59 \%$ $\mathrm{v} / \mathrm{w}$, followed by practically similar but lower yield value for the flowers part $(0.49 \%)$. Alternatively, the stems part yielded a very weak value of EO accounting for only $0.05 \%$. When compared with literature, the obtained yields were lower than reported from Egypt ( $0.9 \%$ for all parts) (El-Shazly et al. 2004) and Iran (0.7; 0.25 and $0.15 \%$ for flowers, leaves and stems, respectively) (Motavalizadehkakhky et al. 2013a, b). 
The percentage composition of the EOs of the different parts (flowers, leaves and stems) are listed in Table 1. GC and GC/MS analysis of the plant EOs led to the identification and quantification of twenty-eight constituents representing $69.12-89.64 \%$ of the total volatile oils. Quantitative and qualitative differences between the EOs of different parts studied were observed.

In the EO extracted from A. santolina flowers, 28 compounds were identified, corresponding to $89.64 \%$ of the total oil composition. It contained $87.00 \%$ of monoterpene derivatives. The oxygenated monoterpenes $(79.94 \%)$ were prevalent compared to the monoterpene hydrocarbons $(7.06 \%)$. Furthermore, the oxygenated sesquiterpenes accounted for $1.14 \%$ only. The main constituent in the A. santolina flowers
EO was (68.12\%), followed by 1,8-cineole (6.25\%). Besides, the most significant minor components were $\alpha$-terpineol $(2.84 \%)$ and camphene $(2.77 \%)$.

In the EO obtained from the leaves part, 19 compounds, comprising $85.43 \%$ of the oil, were detected. The sesquiterpenes composed $1.53 \%$, while the monoterpenes made up $83.27 \%$ of the oil, of which the monoterpenes hydrocarbons had the most important contribution (79.27\%). In addition, camphor $(65.17 \%)$ was also the main constituent of this oil. The other main compounds were also $\alpha$-terpineol $(5.35 \%)$, 1,8-cineole (4.77\%) and camphene (1.46\%).

The stems EO was constituted by just 9 identified compounds. This EO showed a high percentage of monoterpenes hydrocarbons $(65.91 \%)$ and oxygenated sesquiterpenes
Table 1 Chemical composition of essential oils from different parts of A. santolina L.

\begin{tabular}{|c|c|c|c|c|c|c|c|}
\hline \multirow[t]{2}{*}{ No. } & \multirow[t]{2}{*}{ Components } & \multirow[t]{2}{*}{$\mathrm{RI}^{\mathrm{a}}$} & \multirow[t]{2}{*}{$\mathrm{RI}^{\mathrm{b}}$} & \multicolumn{3}{|c|}{$\mathrm{GC}$ area $\%$} & \multirow[t]{2}{*}{ Identification } \\
\hline & & & & Flowers & Leaves & Stems & \\
\hline 1 & Tricyclene & 1011 & 919 & 0.19 & - & - & MS, RI \\
\hline 2 & $\alpha$-Pinene & 1022 & 929 & 1.51 & 0.92 & - & MS, RI \\
\hline 3 & Camphene & 1061 & 942 & 2.77 & 1.46 & - & MS, RI \\
\hline 4 & $\beta$-Pinene & 1102 & 970 & 0.65 & 0.45 & - & MS, RI \\
\hline 5 & Sabinene & 1117 & 963 & 0.34 & 0.26 & - & MS, RI \\
\hline 6 & $\alpha$-Terpinene & 1184 & 1008 & 0.19 & 0.22 & - & MS, RI \\
\hline 7 & Limonene & 1206 & 1022 & 0.40 & 0.34 & - & MS, RI \\
\hline 8 & 1,8-Cineole & 1218 & 1018 & 6.25 & 4.77 & 0.70 & MS, RI \\
\hline 9 & $\gamma$-Terpinene & 1250 & 1046 & 0.47 & 0.35 & - & MS, RI \\
\hline 10 & (E)- $\beta$-Ocimene & 1277 & - & 0.24 & - & - & MS, RI \\
\hline 11 & $p$-Cymene & 1287 & 1011 & 0.13 & - & - & MS, RI \\
\hline 12 & $\alpha$-Terpinolene & 1299 & 1076 & 0.17 & - & - & MS, RI \\
\hline 13 & cis-Sabinene hydrate & 1510 & 1050 & 0.35 & 0.28 & - & MS, RI \\
\hline 14 & $\alpha$-Campholenal & 1493 & 1102 & - & - & - & MS, RI \\
\hline 15 & Camphor & 1518 & 1118 & 68.12 & 65.17 & 55.72 & MS, RI \\
\hline 16 & trans-Sabinene hydrate & 1544 & - & 0.23 & - & - & MS, RI \\
\hline 17 & Linalool & 1550 & 1081 & - & 0.23 & 2.04 & MS, RI \\
\hline 18 & Pinocarvone & 1563 & 1133 & - & - & - & MS, RI \\
\hline 19 & cis-p-Menth-2-en-1-ol & 1577 & 1105 & 0.60 & 0.75 & - & MS, RI \\
\hline 20 & Bornyl acetate & 1592 & - & 0.66 & 0.35 & - & MS, RI \\
\hline 21 & Terpinen-4-ol & 1615 & 1157 & 1.21 & 1.40 & 1.95 & MS, RI \\
\hline 22 & Myrtenal & 1667 & 1163 & - & - & - & MS, RI \\
\hline 23 & $\alpha$-Terpineol & 1705 & - & 2.84 & 5.35 & 2.76 & MS, RI \\
\hline 24 & Borneol & 1715 & 1133 & 0.30 & 0.28 & 1.19 & MS, RI \\
\hline 25 & Myrtenol & 1794 & 1175 & 0.62 & 1.32 & 1.55 & MS, RI \\
\hline 26 & Cayophyllene oxide & 1990 & - & 1.00 & 1.30 & 2.02 & MS, RI \\
\hline 27 & Caryophyllenol II & 2230 & - & 0.14 & 0.23 & - & MS, RI \\
\hline 28 & (E,E)-Farnesyl acetate & 2279 & - & 0.26 & - & 1.19 & MS, RI \\
\hline $\begin{array}{l}\text { Essential oil } \\
\text { yield \% (v/w) }\end{array}$ & & & & 0.49 & 0.59 & 0.05 & \\
\hline
\end{tabular}

Compounds are listed in order to their elution on the UB-Wax column

Bold vlaues are refering to the main identified components of the essential oils for each plant part

${ }^{a}$ Retention indices on the UB-Wax column relative to $\mathrm{C}_{8}-\mathrm{C}_{24} n$-alkanes

${ }^{\mathrm{b}}$ Retention indices on the SPB- 1 column column relative to $\mathrm{C}_{8}$ to $\mathrm{C}_{24} n$-alkanes 
Table 2 Principal chemical classes in the essential oils from A. santolina $\mathrm{L}$. flowers, leaves and stems as a percentage of the total essential oil

\begin{tabular}{llll}
\hline Chemical classes & Flowers & Leaves & Stems \\
\hline Monoterpene hydrocarbons & 7.06 & 4.00 & 0.00 \\
Oxygen containing monoterpenes & 79.94 & 79.27 & 65.91 \\
Total Monoterpenes & 87.00 & 83.27 & 65.91 \\
Sesquiterpenes hydrocarbons & - & - & - \\
Oxygen containing sesquiterpenes & 1.14 & 1.53 & 2.02 \\
Esters & 1.50 & 0.63 & 1.19 \\
Total identified & 89.64 & 85.43 & 69.12 \\
\hline
\end{tabular}

(24.5\%). The oxygenated monoterpenes were the most important derivatives identified, which represented like the two other oils, by camphor $(55.72 \%)$. The other main compounds of the stems volatile oil were $\alpha$-terpineol (2.76\%), linalool $(2.04 \%)$ and terpinen-4-ol (1.95\%) among others.

The examination of the percentages of classes of the different parts studied (Table 2), reveals some similarities and some differences. The oils were rich in oxygenated monoterpenes $(65.91-79.94 \%)$, but poorer in monoterpenes hydrocarbons $(0.0-7.06 \%)$ and oxygenated sequiterpenes $(1.14-2.02 \%)$. On the other hand, the sequiterpenes hydrocarbons were not detected among the identified components. The esters class was present with low percentages (0.63-1.5\%). It was found that a large number of identified components (camphor, 1,8-cineole, camphene, limonene, etc.) were decreasing in the following order flowers $>$ leaves $>$ stems (Table 1). Inversely, there were some components which were exhibiting increasing percentages in the same previous mentioned order (linalool, cayophyllene oxide, terpinen-4-ol, myrtenol and borneol). The main difference between the EO compositions of the stems and both flowers and leaves were the lower content of major compound camphor in the EO of stems and the relatively higher content of the minor component linalool for this same plant part (2.04\% Vs $0.0 \& 0.23 \%)$. Finally, the stems EO was also characterized by the absence of many minor components indentified for the EOs obtained from the flowers and the leaves parts.

The comparison of the obtained results by the current investigation with earlier few reports of the same plant species originating from different countries: Egypt (El-Shazly et al. 2004) and Iran (Motavalizadehkakhky et al. 2013a, b) revealed with evidence that our oils were quite different from the others in terms of its major constituents.

As it was mentioned in the following references (Orav et al. 2006; Rahimmalek et al. 2009), the percentage of the total oil and compounds are influenced by the correlate between different conditions of climate, soil, irrigation, age, variety and morphological of the plant, genetic and their geographic origin, effect of biosynthesis or degradation of certain components. On the other hand, there are considerable the accumulation of the EOs and changes in their compounds in vegetative parts during their development and other phytochemical features.

\section{Conclusion}

The results of this work gave a new contribution to the specific chemical composition of the essential oils obtained from different parts for A. santolina growing in Algeria. The results demonstrated clearly some similarities, but in the mean time spotted some differences in terms of chemical compositions of the studied parts. The results suggests a camphor-rich chemotype of all vegetative parts decreasing in the order (flowers $>$ leaves $>$ stems) for this plant volatile oils that could be used as a base research to find the other probable reasons for phytochemicals use of these specific essential oils.

\section{Compliance with ethical standards}

\section{Ethical statement N/A.}

Conflict of interest This manuscript described has not been published before; not under consideration for publication anywhere else; and has been approved by all co-authors.

\section{References}

Abd-Alla HI, Shalaby NM, Hamed MA, El-Rigal NS, Al-Ghamdi SN, Bouajila J (2016) Phytochemical composition, protective and therapeutic effect on gastric ulcer and $\alpha$-amylase inhibitory activity of Achillea biebersteinii Afan. Arch Pharmacal Res 39:10-20

Al-Awwadi N (2010) Effects of Achillea santolina extracts and fractions on human platelet aggregation in vitro and on rat arteriovenous shunt thrombosis in vivo. Thi-Qar Med J 4:131-141

Al-Awwadi N (2013) Acute and chronic hypoglycaemic effect of Achillea santolina aqueous leaves extract. Int J Med Plants Res 2:129-134

Al-Hindawi MK, Al-Deen IH, Nabi MH, Ismail MA (1989) Antiinflammatory activity of some Iraqi plants using intact rats. J Ethnopharmacol 26:163-168

Ali EM, Abd El-Moaty H (2017) Antifungal activity of Achillea santolina L. and Calendula officinalis L. Essential oils and their constituents against fungal infection of liver as complication of cyclophosphamide therapy. J Essent Oil Bear Plants 20:1030-1043. https://doi.org/10.1080/0972060X.2017.1362998

Alkofahi A, Batshoun R, Owais W, Najib N (1996) Biological activity of some Jordanian medicinal plant extracts. Fitoterapia $67: 435-442$

Al-Snafi AE (2013) Chemical constituents and pharmacological activities of milfoil (Achillea santolina). A review. Int J Pharm Tech Res 5:1373-1377

Ardestani A, Yazdanparast R (2006) Achillea santolina reduced oxidative stress in the liver of streptozotocin-induced diabetic rats. Pharmacologyonline 3:298-308 
Ardestani A, Yazdanparast R (2007) Antioxidant and free radical scavenging potential of Achillea santolina extracts. Food Chem 104:21-29

Bader A, Flamini G, Cioni PL, Morelli I (2003) Essential oil composition of Achillea santolina L. and Achillea biebersteinii Afan. collected in Jordan. Flavour Fragr J 18:36-38

Bali EB, Açık L, Elçi P, Sarper M, Avcu F, Vural M (2015) In vitro anti-oxidant, cytotoxic and pro-apoptotic effects of Achillea teretifolia Willd extracts on human prostate cancer cell lines. Pharmacogn Mag 11:S308-S315. https://doi.org/10.4103/09731296.166060

Benedek B, Kopp B, Melzig MF (2007) Achillea millefolium L. s.I.-is the anti-inflammatory activity mediated by protease inhibition? J Ethnopharmacol 113:312-317

Berramdane T, Gourine N, Bombarda I, Yousfi M (2018) New chemotype of essential oil of Achillea santolina $\mathrm{L}$. collected from different regions of Algeria. J Food Meas Charact. https://doi. org/10.1007/s11694-018-9793-5

Bremer K (1994) Asteraceae: cladistics and classification. Timber Press, Portland

El-Shazly AM, Hafez SS, Wink M (2004) Comparative study of the essential oils and extracts of Achillea fragrantissima (Forssk.) Sch. Bip. and Achillea santolina L. (Asteraceae) from Egypt. Pharmazie 59:226-230

Ghavami G, Sardari S, Shokrgozar M (2010) Anticancerous potentials of Achillea species against selected cell lines. J Med Plants Res 4:2411-2417

Khalil A, Dababneh BF, Al-Gabbiesh AH (2009) Antimicrobial activity against pathogenic microorganisms by extracts from herbal Jordanian plants. J Food Agric Environ 7:103-106

Khoori V, Nayebpour S, Ashrafian Y, Naseri M (1999) Effects of the Methanol extract of Achillea Santolina on the electrophysiological characteristics of isolated atrioventricular node of male rat. J Gorgan Univ Med Sci 1:5-15

Mohamed MIE, Abdelgaleil SAM (2008) Chemical composition and insecticid paoltentia olf essential oils from Egyptian plant asgainst Sitophil uosryzae (L.) (Coleoptera: Cruculionidae) and Tribolium castaneum (Herbst) (Coleoptera: Tenebrionidae). Appl Entomol Zool 43:599-607

Motavalizadehkakhky A, Ebrahimi Z, Emamiyan R, Mohamadian A, Abedi F (2013a) Chemical compositions of essential oils of different parts and extract of Achillea santolina L. from Iran. Asian J Chem 25:6372-6376

Motavalizadehkakhky A, Shafaghat A, Zamani HA, Akhlaghi H, Mohammadhosseini M, Mehrzad J, Ebrahimi Z (2013b) Compositions and the in vitro antimicrobial activities of the essential oils and extracts of two Achillea species from Iran. J Med Plants Res 7:1280-1292

Mustafa MA, Al-Khazraji A (2008) Effect of some plant extracts on the Culex pipiens molestus Forskal larvae Iraqi. J Vet Sci 22:9-12

Nenaah GE (2014) Chemical composition, insecticidal and repellence activities of essential oils of three Achillea species against the Khapra beetle (Coleoptera: Dermestidae). J Pest Sci 87:273-283

Orav A, Arak E, Raal A (2006) Phytochemical analysis of the essential oil of Achillea millefolium L. from various European Countries. Nat Prod Res 20:1082-1088

Quézel P, Santa S, Schotter O (1962) Nouvelle flore de l'Algerie et des regions desertiques meridionales. Tome II. Centre National de la Recherche Scientifique, Paris

Rahimmalek M, Tabatabaei BES, Etemadic N, Goli SAH, Arzani A, Zeinali H (2009) Essential oil variation among and within six Achillea species transferred from different ecological regions in Iran to the field conditions. Ind Crops Prod 29:348-355

Sökmen A, Vardar-Ünlü G, Polissiou M, Daferera D, Sökmen M, Dönmez E (2003) Antimicrobial activity of essential oil and methanol extracts of Achillea sintenisii Hub. Mor. (Asteraceae). Phytother Res 17:1005-1010

Twaij HA, Elisha EE, Kery A, Faraj A-S (1988) Evaluation of the insecticidal and insect repellent effects of Achillea santolina. Int J Crude Drug Res 26:169-171

Ünlü M, Daferera D, Dönmez E, Polissiou M, Tepe B, Sökmen A (2002) Compositions and the in vitro antimicrobial activities of the essential oils of Achillea setacea and Achillea teretifolia (Compositae). J Ethnopharmacol 83:117-121

Yaeesh S, Jamal Q, Khan Au, Gilani AH (2006) Studies on hepatoprotective, antispasmodic and calcium antagonist activities of the aqueous-methanol extract of Achillea millefolium. Phytother Res 20:546-551

Zaringhalam J, Akbari A, Tekieh E, Manaheji H, Rezazadeh S (2010) Achillea santolina reduces serum interlukin-6 level and hyperalgesia during complete Freund's adjuvant-induced inflammation in male Wistar rats J Chin. Integr Med 8:1180-1189 